\title{
SENSE ORGANS, NERVOUS CONTROL, AND MOVEMENT IN MEDUSAE
}

$\operatorname{AUTHOR(S):~}$

Tamasige, Mituo

CITATION:

Tamasige, Mituo. SENSE ORGANS, NERVOUS CONTROL, AND MOVEMENT IN MEDUSAE. PUBLICATIONS OF THE SETO MARINE BIOLOGICAL LABORATORY 1973, 20: 595-596

\section{ISSUE DATE:}

1973-12-19

URL:

http://hdl.handle.net/2433/175756

RIGHT: 


\title{
SENSE ORGANS, NERVOUS CONTROL, AND MOVEMENT IN MEDUSAE
}

\author{
Mituo TAMASIGE \\ Zoological Institute, Faculty of Science, Hokkaido University, Sapporo, Japan
}

\begin{abstract}
The paper, read at the symposium, based mostly on the author's recent work partly published under the title of "The marginal sense organ of medusae" in the Bulletin of the Marine Biological Station of Asamushi, Tohoku University, vol. 13, nos. 3/4 (1969), pp. 211-214. And it was thought that the new interesting findings were added to the paper presented at the floor of symposium. However, the author found the data was not sufficient enough to explain the mechanism of nervous control of sense organ. Efforts have been made to enrich the data, but unfortunately this has not yet been achieved. Therefore, the author would like to ask the participants to the symposium and the readers of this volume for their generosity to admit the publication of his full paper in near future.
\end{abstract}

\begin{abstract}
From the observation of swimming movement of the jellyfish, Dactylometra pacifica GoETTE, it was found that not only the umbrella was closed and opened but also a motion wave was propagated from the centre to margine. Thus, the animal moved forward smoothly, unlike Obelia and the freshwater medusae which advance intermittently.

Dactylometra has eight sense organs arranged in radial symmetry in the marginal part of the umbrella. Each sense organ sends nerve impulses to pulsate to the umbrella muscle. In spite of the fact that the impulses were sent off from the umbrella margine, the muscular contraction began from the central part of the umbrella and propagated to the marginal part. This was confirmed by recording the movements of both the central and the marginal muscles, and at the same time the propagating velocity of contraction wave was measured to be $28 \mathrm{~cm} / \mathrm{sec}$ at $22^{\circ} \mathrm{C}$.

The marginal sense organ containing the statocyst is a pace maker of the subumbrella muscle and an output monitor of the subumbrella muscle activity to maintain. the equilibrium orientation of the jellyfish body. It is a kind of feedback system to control the jellyfish swimming.

The anthomedusa Polyorchis karafutoensis KISHINOUYe has no statocyst, but an ocellus is present on the outer surface of the proximal end of each tentacle. It was found that the ocellus sends the nervous impulses to initiate and control the bell pulsation and serves in keeping the equilibrium orientation of the medusa body. There has been little report showing the case of equilibrium orientation maintained by photoreceptor instead of statocyst in lower invertebrates, although there are many such cases in higher vertebrates which can compensate the deficiency of equilibrium sense organ with the visual system.
\end{abstract}




\section{DISCUSSION}

MACKIE: You said that Polyorchis does not need statocysts as it can use its ocelli for orientation. However, some other Hydromedusae have both ocelli and statocysts (e.g. Tiaropsis sp.).

TAmasige: I stated only in the case of "Anthomedusa" (e.g. Polyorchis) which has no statocyst, but not in the case of Hydromedusae in general.

Passano: 1) Please describe in more detail the histological method used and the appearance of the neuromuscular junctions of the scyphomedusan subumbrella. 2) It seems to me (PASSANo: Amer. Zoologist, 3, 1965) that the reason for the initial contraction of the central subumbrellar swimming muscles, followed later by the contraction of the more peripheral muscle (although the latter is close to the marginal pacemaker) is because of the long neuromuscular delay in the latter, over $700 \mathrm{mS}$. This long delay would cause the swimming beat apparently to originate in the center of the medusa, and spread outward.

TAMASIGE: 1) I have observed only on the preparation of ordinary vital staining with methylene blue. I think it is desirable that further structural investigation (e.g. by electron-microscopy) will be made. 2) At first, I supposed as your finding (1965). But my measurement on the neuromuscular synaptic delay showed almost the same between the central and the marginal parts of the subumbrella.

Passano: (in reply to Dr. TAmasige's answer to 2) I believe that $\mathrm{Mg}^{++}$may block muscle contraction before blocking muscle cell electrical activity, so that the pulses you record $0.2 \mathrm{mS}$ before muscle contraction may not be nerve pulses.

TAMASIGE: In my answer to your question (2), I made a mistake to tell the synaptic delay incorrectly. It was not $0.2 \mathrm{mS}$, but $0.2 \mathrm{sec}$. I used 5 times concentration of $\mathrm{Mg}^{++}$ions of the normal sea water to block the neuromuscular transmission. I obtained the synaptic delay comparing the velocity of neural conduction with the velocity of muscular conduction and the velocity of the whole conduction. 